\title{
Compounds Antioxide of Extract Yellow and Green Bamboo Shoot
}

\section{Edy Soesanto ${ }^{1}$}

${ }^{1}$ Universitas Muhammadiyah Semarang

\section{Article Info}

\section{Article History: \\ Accepted Jan 15th 2018}

Key words:

Antioxidant drugs

Bamboo shoots

Antiaterosklerosis

\begin{abstract}
Bamboo shoot is a plant that is very easy to find in Indonesia and can grow anywhere, bamboo shoot very cheap and has been used by people in the world as food ingredients since time ago. Beside that, bamboo shoot also has a function associated with the nature of hipokolesterolemi, so it can be used as an alternative non-pharmacological treatment or as a traditional medicine derived from medicinal plants (complementary therapies). This research is very determine the levels of phenol, plavonoid, and vitamin $\mathrm{E}$ from bamboo shoots yellow and green bamboo. Bamboo bamboo in thinly sliced and dried with $80^{\circ} \mathrm{C}$ oven for 24 hours and mashed to bamboo bamboo shoots and then extraction using $70 \%$ ethanol to be analyzed antioxidant content of phenol, plavonoid, and vitamin $\mathrm{E}$ by using spectrophotometer. The result of antioxidant compound, antioxidant compound of Vitamin E bamboo green bamboo shoot from yellow bamboo extract is $0,2864 \%$, phenol antioxidant compound in bamboo green bamboo shoot extract bigger than yellow bamboo extract that is $2,3385 \%$, antioxidant compound Plavonoid bamboo green bamboo shoot extract more great when compared with yellow bamboo extract that is equal to $0.02778 \%$. Thus both bamboo shoot extract has a good antioxidant potential and can be used as a traditional medicine antiaterosklerosis derived from medicinal plants (complementary therapies).
\end{abstract}

\section{PENDAHULUAN}

Kasus Penyakit Jantung Koroner di Indonesia semakin sering ditemukan karena pesatnya perubahan gaya hidup. Meski belum ada data epidemiologis pasti, angka kesakitan/kematiannya terlihat cenderung meningkat. Hasil Survei Kesehatan Nasional tahun 2001 menunjukkan tiga dari 1.000 penduduk Indonesia menderita PJK. Riset Kesehatan Dasar pada 2007 di Indonesia yang dilakukan oleh Departemen Kesehatan menyebutkan penyakit jantung koroner ini merupakan penyebab kematian terbesar ke-9 dan ke-11. Dengan 5,1 persen dari semua kematian yang disebabkan oleh penyakit jantung iskemia dan 4,6 persen disebabkan penyakit jantung. Secara kumulatif penyakit jantung menjadi penyebab kematian kedua tertinggi di Indonesia dengan persentase 9,7 persen.

Sebagian besar Penyakit Jantung Koroner terjadi akibat penurunan suplai oksigen (iskemia) pada otot jantung. Penyumbatan pembuluh darah koroner terjadi akibat adanya proses ateroklerosis (perkapuran),

Corresponding author:

Edy Soesanto 
yang diawali dengan penimbunan lemak pada lapisan-lapisan pembuluh darah tersebut (Ganong,1983). Kolesterol yang berlebihan dalam pembuluh darah akan mengalami oksidasi dan mengalami interaksi dengan sel makrofag dan substansi biologik lainnya akan membentuk sel busa (foam cell) yang akan menumpuk dalam dinding pembuluh darah, kemudian menyusup kedinding arteri dan membentuk suatu kerak / plak. Kerak atau plak tersebut akan pecah dan akan memasuki aliran darah keseluruh tubuh dan gumpalan lemak tersebut akan menyumbat pada pembuluh arteri dinding jantung (arteria koroner). Terhambatnya aliran darah kedinding jantung mengakibatkan kematian sel otot jantung dan mengakibatkan keadaan yang fatal dan disebut miokard infarct.

Faktor yang mungkin menjadi penyebab terjadinya peningkatan kasus arterosklerosis adalah gaya hidup (life style); mulai dari pola makan yang tidak sehat sampai kurangnya aktivitas olah raga serta persepsi individu yang keliru terhadap penyakit arterosklerosis. Pola makan tidak sehat meliputi antara lain diet tinggi lemak dan karbohidrat, makanan dengan kandungan garam sodium yang tinggi, rendahnya konsumsi makanan mengandung serat serta kebiasaan merokok dan minum minuman beralkohol.(Soesanto E, 2010). Penurunan kadar kolesterol sering dilakukan oleh masyarakat dengan mengkonsumsi obat hipolipidemia, tetapi harga obat-obatan hipolipidemia sangat mahal, menyebabkan tidak semua orang dapat menjangkaunya. Pemakaian obat sintesis sering menimbulkan efek samping seperti nyeri lambung, nyeri abdomen, urtikaria, disuria, penurunan berat badan, ikhtiosis, insomnia, depresi, dan dysgeusia (Kamaluddin, 1992) dan adanya kontraindikasi terhadap penyakit tertentu yang juga diderita oleh penderita aterosklerosis, sehingga tidak semua orang dapat menggunakannya.

Pencarian obat hipolipidemia terutama yang berasal dari alam dan tumbuhan terus dilakukan. Obat-obatan dari tumbuhan selain mudah didapat harganya murah, juga memiliki efek samping yang kecil sehingga relatif aman jika dibandingkan obat-obatan sintesis. Tumbuhan merupakan sumber senyawa kimia, baik yang sudah diketahui maupun yang belum diketahui jenisnya, dimana banyak diantaranya berpotensi sebagai dasar bahan obatobatan. Salah satu tanaman yang bersifat hipolipidemia adalah rebung (shoot bamboo) sebagai dasar bahan obat-obatan.

Rebung bambu dipercaya untuk menurunkan kadar kolesterol darah, obat sakit kuning/lever (sirosis hati), obat bengkak, batuk berdahak dan demam. Serat rebung yang mengandung lignin (insoluble fiber), pectin dan glucans (soluble fiber) mempunyai efek mengikat zat-zat organik seperti asam empedu dan kolesterol sehingga menurunkan jumlah asam lemak di dalam saluran pencernaan (Olwin, 2005). Pengikatan empedu oleh serat juga menyebabkan asam empedu keluar dari siklus enterohepatik, karena asam empedu yang disekresi ke usus tak dapat diabsorbsi tetapi terbuang ke dalam feses. Penurunan jumlah asam empedu menyebabkan hepar harus menggunakan kolesterol sebagai bahan untuk membentuk asam empedu. Hal ini yang menyebabkan serat dapat menurunkan kadar kolesterol. Diduga pula bahwa dengan keberadaan serat akan menghambat emulsifikasi lemak dan kolesterol oleh garam empedu, sehingga kolesterol akan terikat oleh serat yang kemudian akan dikeluarkan melalui ekskreta (Hernawati, 2005).

Beberapa studi atau penelitian membuktikan bahwa rebung dapat menurunkan tekanan darah karena kandungan kaliumnya yang tinggi dan pithopenolnya merupakan antioksidan (Parekh.J and Chanda.S,2007) Menurunkan glukosa darah, profil lipid, fungsi hepatik dan gejala sembelit (Park.E.J, John.D.Y, 2009; Jiao.J,2008; Jiao.J, 2008). Kandungan bioaktif lignophenol mempunyai peran sebagai anti oksidan dan 
menekan apoptosis pada sel neuroblastoma SH-SY5Y (Akao Y ,2004; $\mathrm{Hu} \mathrm{CH}, 2000$ ). Daun bambu yang kaya dengan polyphenol , C-glucosides and p-coumaric acid merupakan senyawa antioksidan (Lu.B,2006; Zhang.Y,2007). Kandungan Tricin (5,7,4'-trihydroxy-3',5'dimethoxyflavone) dalam daun bambu merupakan senyawa antioksidan terhadap pertumbuhan sel kanker (Jiao.J,200). Rebung dapat juga digunakan sebagai antiinflamasi dan menghambat proliferasi sel karsinoma ascite Ehrlich lebih kuat dibanding Catharanthus roseus yang selama ini dikenal sebagai tanaman obat antikanker (Rana, 2008).

Berdasarkan uraian diatas bahwa rebung merupakan tanaman yang sangat mudah dijumpai di Indonesia dan dapat tumbuh dimana saja, secara ekonomis rebung sangat murah serta telah digunakan oleh masyarakat di dunia sebagai bahan pangan sejak jaman dahulu. Selain sebagai bahan makanan rebung juga memiliki fungsi yang terkait dengan sifat hipokolesterolemi, sehingga dapat dijadikan sebagai salah satu alternatif pengobatan non farmakologi atau sebagai obat tradisional yang berasal dari tanaman obat (Complementary Therapy), maka dirasa perlu untuk dilakukan penelitian lebih lanjut. Penelitian ini bertujuan untuk mengetahui kandungan senyawa antioksidan pada rebung bambu kuning dan hijau.

\section{METODE}

\section{Bahan Penelitian}

Bahan yang digunakan untuk diteliti adalah rebung segar yang biasa digunakan sebahan baku pangan dan obat yaitu rebung bambu kuning dan hijau. Diperoleh dari tanaman yang tumbuh dikebun bambu masyarakat di desa Banyumeneng, kecamatan Mranggen, kabupaten Demak, pada bulan mei tahun 2013. Bahan kimia yang digunakan dalam pengujian kadar plavonoid menggunakan larutan standar flavonoid rutin, etanol 70 $\%$, pengujian kadar phenol menggunakan aquades, reagen Folin-Ciocalteu, sodium karbonat jenuh, pengujian kadar vitamin E menggunakan PE. gas nitrogen, toluene, larutan 2,2 bipiridin dalam etanol dan ferri klorida dalam etanol 0,02\% (semuanya dengan grade pa dari Merck). Alat yang digunakan untuk analisis pengujian senyawa antioksidan menggunakan spektrofotometer UV-VIS.

\section{Pembuatan ekstrak rebung}

Rebung dilepas dari kelopaknya dan diiris tipis tipis, direndam dalam air selama 24 jam (tiap 12 jam airnya diganti) kemudian dikeringkan dengan oven pada suhu $800 \mathrm{C}$, digiling dengan mesin sehingga diperoleh serbuk rebung bambu dan dilakukan proses ekstraksi dengan menggunakan etanol 70 $\%$.

\section{Uji Total phenol}

Diambil bahan bahan sebanyak $1 \mathrm{~g}$ ditambahkan dengan aquades $70 \mathrm{ml}$ dalam labu ukur $100 \mathrm{ml}$. Ditambahkan reagen Folin-Ciocalteu sebanyak $5 \mathrm{ml}$. Setelah 1 menit dimasukkan sodium karbonat jenuh sebanyak $15 \mathrm{ml}$. Ditambahkan aquades sampai tepat $100 \mathrm{ml}$, kemudian dilakukan homogenisasi dengan shaker. Sampel didiamkan selama 2 jam. Sampel dibaca dengan menggunakan spektrofotometer pada panjang gelombang $760 \mathrm{~nm}$.

\section{Uji Plavonoid}

Pembuatan larutan standar, menggunakan larutan standar flavonoid rutin, optimasi panjang gelombang, menentukan absorbansi isolat murni senyawa flavonoid, dan kalibrasi hasil pengukuran Larutan standar yang dipakai yaitu senyawa flavonoid rutin dengan konsentrasi 0,10 , 20, 30, 40, dan 50 mg.L-1 masing-masing dibuat $25 \mathrm{~mL}$ dalam pelarut etanol dari larutan standar induk 1000 mg.L-1.

Ditimbang $1000 \mathrm{~g}$ senyawa rutin, dimasukkan dalam gelas piala $100 \mathrm{~mL}$ dan dilarutkan dengan $50 \mathrm{~mL}$ etanol dan diaduk 
hingga homogen, kemudian dipindahkan ke dalam labu takar $1000 \mathrm{~mL}$ dan ditambahkan etanol sampai tanda dan dikocok hingga homogen. Larutan standar induk, diencerkan menjadi 100 mg.L-1 dengan dipipet sebanyak $10 \mathrm{~mL}$. Larutan kemudian diencerkan dengan labu takar $100 \mathrm{~mL}$ dengan etanol sampai tanda batas. Larutan standar 10, 20, 30, 40, dan 50 mg.L1 dibuat dengan dipipet 2,$5 ; 5,0 ; 7,5 ; 10,0$; dan 12,5 mL larutan standar 100 mg.L-1 masing-masing diencerkan dengan pelarut etanol dalam labu takar $25 \mathrm{~mL}$ sampai tanda dan dikocok hingga homogen. Blanko yang digunakan adalah etanol murni.

\section{Menentukan panjang gelombang} maksimum yang akan digunakan dalam pengukuran dengan menggunakan spektrofotometer UV-Vis dengan menggunakan salah satu larutan standar rutin. Langkah selanjutnya adalah penentuan absorbansi larutan standar pada panjang gelombang maksimum dilanjutkan dengan penentuan absorbansi sampel.

Absorbansi fraksi flavonoid dikalibrasikan dengan kurva konsentrasi standar versus absorbansi standar dengan persamaan regresi linear. Hasil yang diperoleh diperhitungkan dengan faktor pengenceran sehingga diperoleh konsentrasi flavonoid yang terdapat dalam ekstrak etanol rebung.

\section{Uji Vitamin E}

Ditimbang sampel yang telah dihaluskan kemudian diekstrasi dengan PE. Campuran divortek sampai seluruh minyak terekstrasi.Hasil ekstrasi dipindahkan dalam labu takar $10 \mathrm{ml}$ kemudian diuapkan dengan gas nitrogen untuk memperoleh minyak.Selanjutnya ditambah $5 \mathrm{ml}$ toluene; 3,5 ml larutan 2,2 bipiridin dalam etanol $0,07 \%(\mathrm{~b} / \mathrm{v})$ dan 0,5 ml ferri klorida dalam etanol $0,02 \%(b / v)$ dan akhirnya ditambah etanol sampai tanda. Sampel divoertek selama beberapa menit sehingga warnanya dapat terbentuk secara sempurna dan dibiarkan selama 1 menit, selanjutnya ditera dengan spektrootometer.

\section{HASIL}

Proses pembuatan ekstrak rebung diperoleh dari rebung bambu segar diiris tipis kemudian dikeringkan dalam oven bersuhu $80 \quad 0 \quad \mathrm{C}$ selama 24 jam dan dihaluskan dengan mesin kemudian dilakukan ekstraksi dengan menggunakan etanol $70 \%$, sehingga didapatkan perubahan berat rebung setelah menjadi ekstrak kering terbesar adalah rebung bambu hijau seperti terlihat dalam tabel 1 . Penyusutan ini terjadi karena banyaknya kandungan air yang terdapat dalam rebung di kedua bambu tersebut, semakin sedikit kadar airnya akan berpengaruh terhadap lama penyimpanan karena air merupakan media yang baik bagi pertumbuhan jamur atau kapang saat dilakukan proses penyimpanan.

Tabel 1. Berat rebung sebelum dan sesudah menjadi serbuk rebung

\begin{tabular}{|c|c|c|c|}
\hline Jenis rebung & $\begin{array}{c}\text { Berat } \\
\text { basah } \\
\text { (gr) } \\
\end{array}$ & $\begin{array}{c}\text { Berat } \\
\text { kering } \\
\text { (gr) }\end{array}$ & $\begin{array}{c}\text { Berat } \\
\text { ekstrak } \\
\text { (gr) }\end{array}$ \\
\hline $\begin{array}{l}\text { Rebung } \quad \text { bambu } \\
\text { kuning }\end{array}$ & 4750 & 365.28 & 339.71 \\
\hline $\begin{array}{l}\text { Rebung } \\
\text { hijau }\end{array}$ & 4950 & 429,2 & 371,97 \\
\hline
\end{tabular}

\section{Kandungan senyawa antioksidan}

Antioksidan adalah senyawa kimia yang dapat menyumbangkan satu atau lebih elektron kepada radikal bebas, sehingga dapat meredam radikal bebas. Antioksidan alami mampu melindungi tubuh dari kerusakan yang disebabkan spesies oksigen reaktif, dan mampu menghambat terjadinya penyakit degeneratif penyakit jantung, arteriosclerosis, kanker, serta gejala penuaan. Hal ini berkaitan dengan kemampuan antioksidan untuk bekerja sebagai inhibitor (penghambat) reaksi oksidasi oleh radikal bebas reaktif yang menjadi salah satu pencetus penyakitpenyakit tersebut serta mampu menghambat peroksidae lipid pada makanan (Suhartono, 2002).

Antioksidan mengurangi aterosklerosis dengan cara menghambat oksidasi LDL 
dalam lesi aterosklerotik dengan sekresi VCAM-1 pada endotel, mengurangi toksisitas LDL yang teroksidasi terhadap sel endotel, sel otot polos dan makrofag, mengurangi degradasi oksidatif akibat nitrit oksida, membatasi vasokonstriksi serta mengurangi tekanan darah (Morel DW.d Corleto PE, Chisolm Gm, 1984). Senyawa antioksidan yang terdapat dalam rebung diantaranya adalah Vitamin E (alfa tokoferol), Plavonoid dan Phenol.

Tabel 2. Hasil analisis kandungan senyawa antioksidan

\begin{tabular}{lccc}
\hline \multirow{2}{*}{$\begin{array}{c}\text { Jenis } \\
\text { rebung }\end{array}$} & \multicolumn{3}{c}{ Kandungan (\%) } \\
\cline { 2 - 4 } & Plavonoid & Phenol & Vitamin E \\
\hline $\begin{array}{l}\text { Bambu } \\
\text { Kuning }\end{array}$ & 0.02335 & 2.3385 & 0.2737 \\
$\begin{array}{l}\text { Bambu } \\
\text { Hijau }\end{array}$ & 0.02778 & 1.9329 & 0.2864 \\
\hline
\end{tabular}

Vitamin E merupakan antioksidan yang cukup kuat dan memproteksi sel-sel membran serta LDL (Low Density Lipoprotein) kolesterol dari kerusakan radikal bebas, membantu memperlambat proses penuaan pada arteri dan melindungi tubuh dari kerusakan sel-sel yang akan menyebabkan penyakit kanker, penyakit hati dan aterosklerosis. Vitamin E berperan dalam menurunkan terjadinya oksidasi LDL, mencegah terjadinya injury pada endotel, menurunkan reaksi inflamasi cytokin, menurunkan agregasi platelet (Maydani.M. 2001). Kandungan Vitamin E yang terdapat dalam ekstrak rebung bambu Hijau lebih tinggi daripada pada ekstrak rebung bambu kuning yaitu besarnya $0.2864 \%$ seperti terlihat dalam tabel 2.

Flavonoid merupakan salah satu kelompok senyawa fenolik yang memiliki sifat antioksidatif serta berperan dalam mencegah kerusakan sel dan komponen selularnya oleh radikal bebas reaktif, serta bioaktifitas sebagai obat dengan cara mendonasikan atom hidrogennya atau melalui kemampuannya mengkelat logam, berada dalam bentuk glukosida (mengandung rantai samping glukosa) atau dalam bentuk bebas yang disebut aglikon. Selain efek kardioprotektif, telah banyak pula hasil penelitian yang menunjukkan bahwa flavonoid mempunyai kontribusi dalam aktivitas anti-proliferatif pada sel kanker manusia (Manthey dan Najla Guthrie ,2002). Hasil analisis seperti pada tabel $2 \mathrm{di}$ temukan bahwa kandungan plavonoid total yang terdapat pada ekstrak rebung bambu hijau lebih tinggi dibandingkan dengan ekstrak rebung bambu kuning yaitu besarnya $0.02778 \%$.

Polifenol merupakan suatu kelompok antioksidan yang secara alami terdapat pada sayur-sayuran, buah-buahan, dan minuman, mempunyai kemampuan menghambat reaksi oksidasi dan menangkap radikal bebas, serta mempunyai aktivitas sebagai antioksidan dan antiradikal. Senyawafenol mampu mencegah oksidasi LDL 20 kali lebih kuat dibandingkan dengan vitamin E. Kandungan Phenol dalam ekstrak rebung bambu kuning lebih banyak daripada ekstrak rebung bambu hijau yang besarnya $2.3385 \%$.

Dengan melihat hasil kandungan senyawa anti oksidan plavonoid, phenol dan vitamin E yang terdapat dikedua ekstrak rebung tersebut, dapat dikatakan bahwa keduanya mempunyai potensi yang tinggi untuk digunakan sebagai bahan obat atau terapi komplementer antioksidan dan tentunya juga bisa digunakan sebagai obat yang dapat mencegah terjadinya hiperlipidemia.

\section{SIMPULAN}

Jumlah senyawa antioksidan phenol pada ekstrak rebung bambu hijau lebih besar dibandingkan ekstrak bambu kuning yaitu besarnya $2.3385 \%$. Jumlah senyawa antioksidan Plavonoid ekstrak rebung bambu hijau lebih besar bila dibandingkan dengan ekstrak bambu kuning yaitu sebesar $0.02778 \%$. Jumlah senyawa antioksidan Vitamin E rebung bambu hijau lebih banyak daripada ekstrak rebung bambu kuning yaitu sebesar $0.2864 \%$. 


\section{REFERENSI}

Akao Y, Seki N, Nakagawa Y, Yi H, Matusumoto K, Ito Y, Ito K, Funaoka M, Maruyama W, Naoi M, Nozawa Y, 2004. A highly bioactive lignophenol derivative from bamboo lignin exhibit a potent activity to suppress apoptosis induced by oxidative stress in human neuroblastoma SH-SY5Y cells. Bio and Med Chem 12:4791-801.

Hanani E, Abdul M, Ryany S. 2005 Identifikasi Senyawa Antioksidan dalamSpons Callyspongia sp dari Kepulauan Seribu. Majalah Ilmu Kefarmasian2:127-133.

Hernawati. 2005. Peran berbagai sumber serat dalam dinamika kolesterol pada individu hiperkolesterolemia dan normokolesterolemia, Bandung (tidak dipublikasikan).

Hu CH, Zhang Y, David DK.2000. Evaluation of antioxidant and prooxidant activities of bambooPhyllostachys nigra ar. enonis eaf extract $n$ vitro. J Agric Food Chem 48(8) 3170-6.

Kamaluddin, MT.1992. Farmakologi Obat Anti Hiperlipidemia. Available in: http://www.cermindunia kedokteran.com.

Maydani.M. 2001. Vitamin E and Atherosclerosis: Beyond Prevention of LDL Oxidation. J. Nutr. 131; 366S-368S,

Morel DW.d Corleto PE, Chisolm Gm. 1984. Endothelial and smooth muscle cells alter low density lipoprotein in vitro by free radical oxidation. Arteriosclerosis. .4: 357-364
Nengah K.P.I, 2009. Efektifitas berbagai cara pemasakan terhadap penurunan kandungan asam sianida berbagai jenis rebung bambu, Agrotekno vol 15, nomor 2, agust 2009-40

Olwin Nainggolan, Cornelis Adimunca 2005. Diet Sehat dengan Serat, Cermin Dunia Kedokteran No. 147, :43 - 46

Parekh.J and Chanda.S. 2007. In vitro antibacterial activity of the crude methanol extract of woodfordia fruticosa kurz flower (lythraceae).Brazillian.J. Microbial. ; 38 : 204 207.

Rana, M., Khanam, J.A. dan Asad-Ud-Daula, M.2008. , Antineoplastic screening of some medicinal plants against Ehrlich ascites carcinoma in mice, J. Med. Sci., 4 (2) :142-145.

Soesanto, E. 2010. Faktor-faktor yang berhubungan dengan praktik pengendalian kesehatan pada lanjut usia Hipertensi di Wilayah kerja Puskesmas Mranggen, Demak, Tesis, UNDIP.

Suhartono, E., Fujiati, Aflanie, I. (2002). Oxygen toxicity by radiation and effect of glutamic piruvat transamine (GPT) activity rat plasma after vitamine $\mathrm{C}$ treatmen, Diajukan pada Internatinal seminar on Environmental Chemistry and Toxicology, Yogyakarta.

Winarno, 1992. Rebung (Teknologi Produksi dan Pengolahan), Jakarta: Pusaka Sinar Harapan.

Winarno, F. G. 1993. Pangan, Gizi, Teknologi dan Konsumen. PT Gramedia. Jakarta. 